\title{
VCP wt Allele
}

National Cancer Institute

\section{Source}

National Cancer Institute. VCP wt Allele. NCI Thesaurus. Code C124933.

Human VCP wild-type allele is located in the vicinity of 9p13.3 and is approximately $17 \mathrm{~kb}$ in length. This allele, which encodes transitional endoplasmic reticulum AT Pase protein, plays a role in maintenance of both the transitional endoplasmic reticulum and the Golgi apparatus. Mutation of the gene is associated with amyotrophic lateral sclerosis 14 and inclusion body myopathy with early-onset Paget disease and frontotemporal dementia 1 (IBMPFD1). 